Commentary

\title{
Learning Not to Fear, Faster
}

\author{
Gregory J. Quirk \\ Department of Physiology, Ponce School of Medicine, Ponce, Puerto Rico 00732
}

Overcoming our fears is on everyone's "to do" list. However, this is more difficult for some than others, especially those suffering from posttraumatic stress disorder (PTSD). To understand how the brain learns to feel safe, researchers have turned to extinction of classically conditioned fear. In extinction, mice learn that a tone previously paired with a footshock no longer predicts the shock and is therefore no longer dangerous. One promise of extinction research is the possibility of accelerating extinction learning, with the hope of facilitating extinction-based exposure therapy used to treat PTSD sufferers.

In this issue of Learning and Memory, Cain et al. (2004) make good on that promise by showing that the noradrenergic antagonist yohimbine accelerates extinction learning in mice. Yohimbine increases release of norepinephrine from nerve terminals by blocking $\alpha_{2}$ autoreceptors. Mice given systemic yohimbine extinguished their conditioned freezing responses in far fewer trials than controls. Mice injected with saline required 30 trials to extinguish freezing to the level that yohimbine-injected rats reached after only five trials. Interestingly, yohimbine did not increase the maximal level of extinction achieved after 30 trials, suggesting that norepinephrine modulates but does not mediate extinction. In support of this, blocking $\beta$ noradrenergic receptors with propranolol did not have a significant effect on the rate of extinction.

A clue to how yohimbine might affect extinction comes from another recent study from the same authors (Cain et al. 2003). They found, somewhat counterintuitively, that rats learned extinction better if the interval between extinction trials was short (trial massing). Increasing the delay between extinction trials (trial spacing) decreased the effectiveness of extinction. In fact, with an intertrial interval of $10 \mathrm{~min}$, rats actually increased their fear during extinction training. Because extinction trials can also serve as reminders of conditioning, Cain et al. (2003) suggest that extinction can trigger two opposing processes: fear incubation or fear extinction, depending on the intertrial interval. In the present study, Cain et al. (2004) replicated their observation that fear was not reduced by spaced extinction training. Spaced training with yohimbine, however, resulted in significant extinction, whereas spaced training with propranolol led to increased fear. Thus, noradrenergic activity (or trial massing) appears to tip the scales in favor of extinction, but noradrenergic blockade (or trial spacing) favors incubation (see Fig. 1).

These findings suggest the interesting possibility that incubation acts as a safeguard against accidental learning of extinction; incubation must be overcome before extinction can be initiated. An obvious implication for exposure therapy is that exposure sessions might be more effective if given frequently over a short period, to "kick-start" the extinction process. Yohimbine given in conjunction with exposure therapy might reduce the number of sessions needed, or might convert unsuccessful therapies into successful ones.

E-MAIL gjquirk@yahoo.com; FAX (787) 844-1980.

Article and publication are at http://www.learnmem.org/cgi/doi/10.1101/ Im.75404.
However, yohimbine might not be popular as an adjunct to exposure therapy because it has been shown to be anxiogenic in both people (Charney et al. 1984) and mice (Blanchard et al. 1993). This could be another clue to its acceleration of extinction, as it is well known that factors increasing conditioned responding during extinction strengthen subsequent memory for extinction (Rescorla 2000). For extinction of fear, this might mean "no pain, no gain." These findings also offer a cautionary note to those considering using propranolol as a treatment for PTSD (Pitman et al. 2002), at least with patients undergoing exposure therapy.

Other recent studies have used different approaches to accelerate extinction of fear. As in many types of learning, longterm retention of extinction requires activation of NMDA glutamate receptors. NMDA antagonists given systemically (Santini et al. 2001) or microinfused into the amygdala (Falls et al. 1992) prevent extinction of conditioned fear. By the same logic, could facilitating NMDA receptors strengthen extinction? The answer appears to be yes. Davis and colleagues showed that microinfusing the partial agonist D-cycloserine into the amygdala strengthened extinction of fear-potentiated startle in rats (Walker et al. 2002). This finding, which has been replicated for extinction of conditioned freezing (Ledgerwood et al. 2003), suggests that extinction may be consolidated in the amygdala via NMDAdependent mechanisms. D-cycloserine, which has been used for decades as a treatment for tuberculosis, is well tolerated and may be another useful adjunct to exposure therapy.

Increasing evidence suggests that consolidation of extinction also involves the medial prefrontal cortex (mPFC). Rats with lesions of mPFC can extinguish fear responses normally, but are unable to recall extinction learning the following day (Morgan et al. 1993; Quirk et al. 2000). This is the same time at which mPFC neurons show increased tone responses (Milad and Quirk 2002), suggesting that mPFC signals extinction memory. Interestingly, high-frequency stimulation of mPFC, either directly (Milad and Quirk 2002) or via its thalamic inputs (Herry and Garcia 2002), strengthens extinction memory. Thus, consolidation of extinction may involve NMDA-mediated long-term potentiation of the

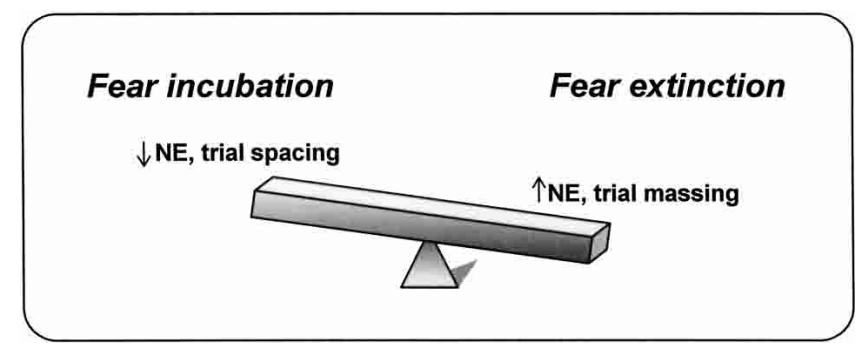

Figure 1 Incubation vs. extinction of conditioned fear. Once mice have learned that a tone predicts a shock, giving the tone repeatedly without the shock leads to extinction of conditioned fear responses. Cain et al. (2004) suggest that extinction training can result in either extinction of fear or incubation of fear, because extinction trials can act as reminders of the tone-shock association. Blocking norepinephrine (with propranolol) or increasing the interval between extinction trials (trial spacing) favors incubation. Facilitating norepinephrine (with yohimbine) or decreasing the interval between tones (trial massing) favors extinction. 
mPFC and/or amygdala. In support of this, GABAergic intercalated cells of the amygdala, which receive input from $\mathrm{mPFC}$ and control amygdala output, exhibit NMDA-dependent long-term potentiation (Royer and Pare 2002). Thus, mPFC and the amygdala may work together to control the consolidation and expression of extinction. In light of the present study, it is interesting to note that yohimbine stimulates c-Fos expression in the mPFC (Singewald et al. 2003).

It is often said that there is nothing to fear but fear itself. This is especially true for people suffering from anxiety disorders. Perhaps understanding how the brain learns safety may finally allow this age-old cycle to be broken.

\section{Editor's Note}

Readers interested in this topic are advised that Learning \& Memory will be publishing a special issue on extinction in September/October.

\section{REFERENCES}

Blanchard, R.J., Taukulis, H.K., Rodgers, R.J., Magee, L.K., and Blanchard, D.C. 1993. Yohimbine potentiates active defensive responses to threatening stimuli in Swiss-Webster mice. Pharmacol. Biochem. Behav. 44: 673-681.

Cain, C.K., Blouin, A.M., and Barad, M. 2003. Temporally massed CS presentations generate more fear extinction than spaced presentations. J. Exp. Psychol. Anim. Behav. Process. 29: 323-333. . 2004. Adrenergic transmission facilitates extinction of conditional fear in mice. Learn. Mem. (this issue).

Charney, D.S., Heninger, G.R., and Breier, A. 1984. Noradrenergic function in panic anxiety. Effects of yohimbine in healthy subjects and patients with agoraphobia and panic disorder. Arch. Gen. Psychiatry 41: 751-763.
Falls, W.A., Miserendino, M.J., and Davis, M. 1992. Extinction of fear-potentiated startle: Blockade by infusion of an NMDA antagonist into the amygdala. J. Neurosci. 12: 854-863.

Herry, C. and Garcia, R. 2002. Prefrontal cortex long-term potentiation, but not long-term depression, is associated with the maintenance of extinction of learned fear in mice. J. Neurosci. 22: 577-583.

Ledgerwood, L., Richardson, R., and Cranney, J. 2003. Effects of D-cycloserine on extinction of conditioned freezing. Behav. Neurosci. 117: 341-349.

Milad, M.R. and Quirk, G.J. 2002. Neurons in medial prefrontal cortex signal memory for fear extinction. Nature 420: 70-74.

Morgan, M.A., Romanski, L.M., and LeDoux, J.E. 1993. Extinction of emotional learning: Contribution of medial prefrontal cortex Neurosci. Lett. 163: 109-113.

Pitman, R.K., Sanders, K.M., Zusman, R.M., Healy, A.R., Cheema, F., Lasko, N.B., Cahill, L., and Orr, S.P. 2002. Pilot study of secondary prevention of posttraumatic stress disorder with propranolol. Biol. Psychiatry 51: 189-192.

Quirk, G.J., Russo, G.K., Barron, J.L., and Lebron, K. 2000. The role of ventromedial prefrontal cortex in the recovery of extinguished fear. J. Neurosci. 20: 6225-6231.

Rescorla, R.A. 2000. Extinction can be enhanced by a concurrent excitor. J. Exp. Psychol. Anim. Behav. Process. 26: 251-260.

Royer, S. and Pare, D. 2002. Bidirectional synaptic plasticity in intercalated amygdala neurons and the extinction of conditioned fear responses. Neuroscience 115: 455-462.

Santini, E., Muller, R.U., and Quirk, G.J. 2001. Consolidation of extinction learning involves transfer from NMDA-independent to NMDA-dependent memory. J. Neurosci. 21: 9009-9017.

Singewald, N., Salchner, P., and Sharp, T. 2003. Induction of c-Fos expression in specific areas of the fear circuitry in rat forebrain by anxiogenic drugs. Biol. Psychiatry 53: 275-283.

Walker, D.L., Ressler, K.J., Lu, K.T., and Davis, M. 2002. Facilitation of conditioned fear extinction by systemic administration or intra-amygdala infusions of D-cycloserine as assessed with fear-potentiated startle in rats. J. Neurosci. 22: 2343-2351. 


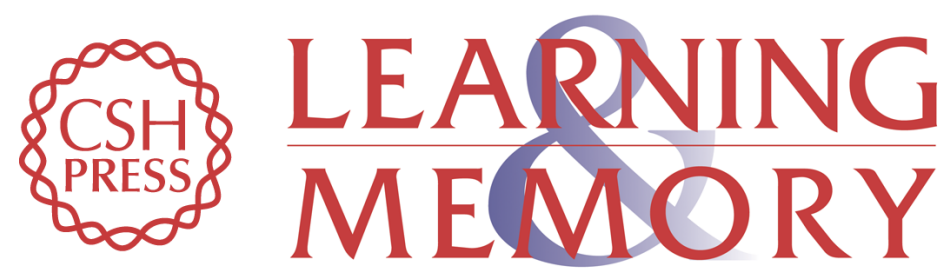

\section{Learning Not to Fear, Faster}

Gregory J. Quirk

Learn. Mem. 2004, 11:

Access the most recent version at doi:10.1101//m.75404

References This article cites 15 articles, 5 of which can be accessed free at: http://learnmem.cshlp.org/content/11/2/125. full.html\#ref-list-1

\section{License}

Email Alerting Service

Receive free email alerts when new articles cite this article - sign up in the box at the top right corner of the article or click here. 